\title{
Seagrass Science is Growing: A Report on the 12th International Seagrass Biology Workshop
}

Hind-Ozan, Edward J. ${ }^{12}$

Jones, Benjamin L. ${ }^{12}$

${ }^{1}$ Sustainable Places Research Institute, Cardiff University, Cardiff CF10 3BA, UK

${ }^{2}$ Project Seagrass, Sustainable Places Research Institute, Cardiff University, Cardiff CF10 3BA, UK

Keywords: seagrass research, seagrass science, seagrass conference, \#oceanoptimism

\section{Abstract}

This conference report describes the programme of the $12^{\text {th }}$ International Seagrass Biology Workshop, its highlights, areas of growth for the workshop, and potential future directions for the workshop series. The report is written with an eye toward where it fits within the field of seagrass research.

\section{Highlights}

- The size and profile of the International Seagrass Biology Workshop is increasing.

- The rising profile of the workshop is in line with the increase in attention for seagrass in the scientific community and media.

- The next iteration of the workshop should consider more social science content.

\section{Introduction}

The $12^{\text {th }}$ International Seagrass Biology Workshop (ISBW12) was the latest meeting in the now biennial International Seagrass Biology Workshop (ISBW) series, which commenced in 1993. Held in Nant Gwrtheyrn, Wales, United Kingdom, 16-21 October 2016, ISBW12 was one of the largest gatherings of seagrass scientists to date (see Figure 1). Reflecting the aim for all ISBWs to help provide answers to on-going global research on seagrass, as well as to provide a space to describe and foster positive management outcomes for these ever more stressed coastal seagrass environments (Coles et al., 2014), a theme 'securing a future for seagrass' was chosen for ISBW12. It signalled the intentions of the meeting's organisers and the co-convening World Seagrass Association (WSA) to mark an important waypoint on the path to greater conservation for seagrass habitats and seagrass-dependent species.

In this conference report, we detail how the growing profile for seagrass science is at least partially due to the activities associated with International Seagrass Biology Workshop (ISBW) meetings, and highlight how ISBW12 might have made conservation action for seagrass more likely. We do this through giving focus to four aspects of the meeting that seem to represent growth for seagrass science. These were (1) the increase in size of the ISBW community and the conference's scientific programme, (2) the high profile of the research presented, (3) the broad coverage of ISBW12 in print and online media, and (4) the clear establishment of a strong social media presence for seagrass scientists and 
enthusiasts. We conclude with thoughts on how seagrass science and conservation can continue to grow through the ISBW series.

\section{Growth in conference size}

Figure 1 illustrates that ISBW12 was among the best-attended ISBWs. The number of delegates that attended ISBW12 was 161, compared to approximately 110 for ISBW11 (Xiaoping Huang, personal communication). They delivered 84 oral and 37 poster presentations on the key conference themes of 'resilience and a changing environment', 'ecosystem services', 'restoration and management', and 'raising the profile of seagrass meadows'; a substantial increase on the respective 46 and 22 at the previous meeting (South China Sea Institute of Oceanology, 2014). The attendance was higher than the previous ISBW maximum of 147 for ISBW6, and the total of 121 presentations was close to the high of 149 at ISBW6 and equal to the second high at ISBW9 (Coles et al., 2014). The increase in delegate numbers and the large number of presentations delivered are indicators of the healthy trajectory of seagrass science as a field of research.

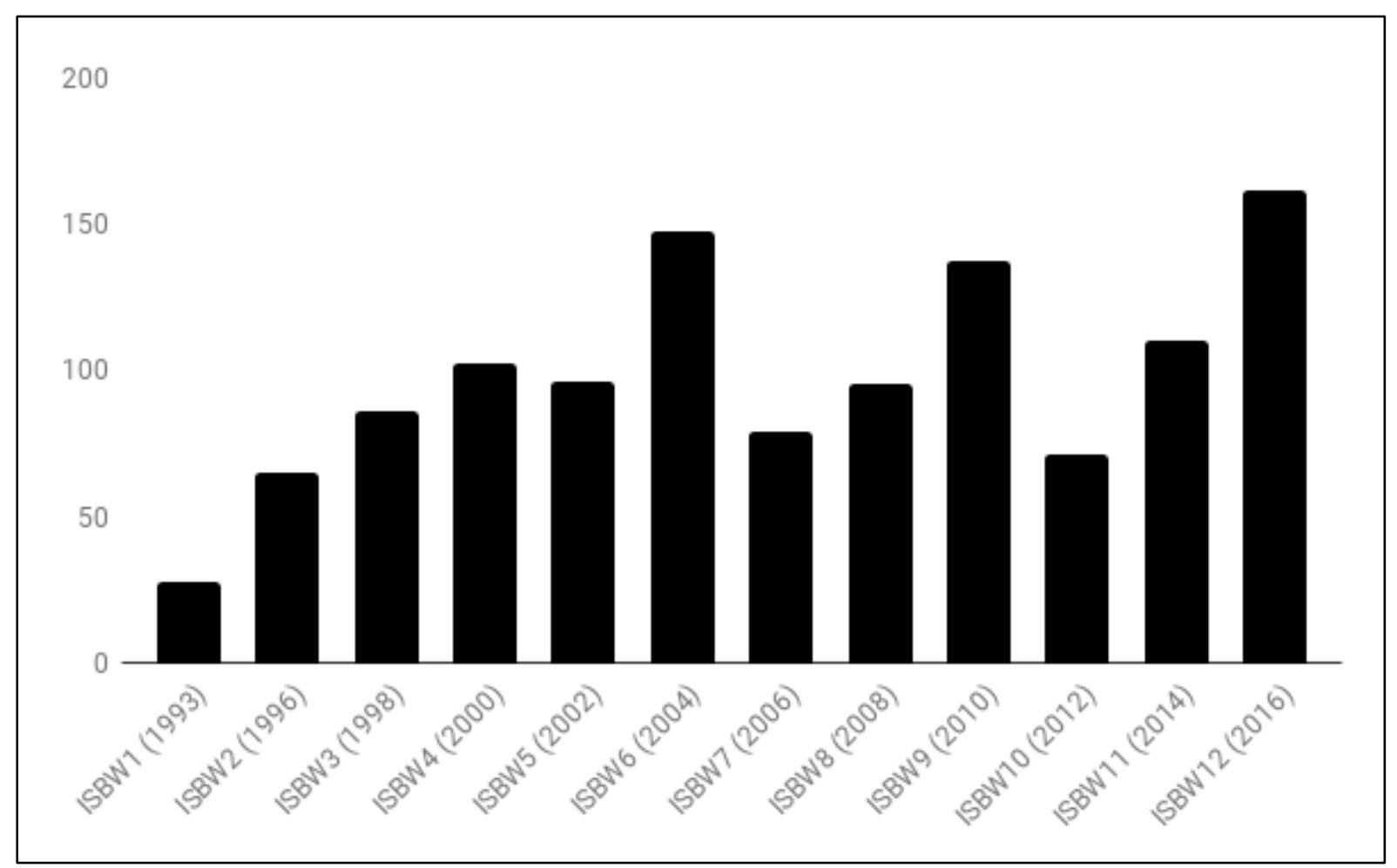

Figure 1. Delegate numbers for each ISBW (Data sources: Coles et al., 2014; Xiaoping Huang, personal communication)

As Table 1 shows, the attendees also included a large contingent of students, two of which were high school students (who presented a poster on their own seagrass research). This high student attendance was not skewed by a presence from a local university, as can sometimes be the case at conferences. Only $31 \%$ of British attendees were students, compared to $35 \%$ across the entire delegation. The suggestion is that 2016 overall turnout will not be an isolated occurrence, as a good number of early career researchers are focussing on seagrass. Given the intensifying calls for more research to assess and foster the reduction of threats to seagrass habitats and the species that depend on them (Orth et 
al., 2006; Unsworth and Cullen, 2010; York et al., 2016) it is extremely encouraging to see the seagrass research community's flagship gathering grow in size during a period where similar events are struggling with decreasing attendances (Stevens et al., 2016).

Table 1. Delegate demographics and nationalities

\section{Delegate Demographics}

\begin{tabular}{|l|l|l|}
\hline Female & 81 & $50 \%$ \\
\hline Male & 80 & $50 \%$ \\
\hline Student & 56 & $35 \%$ \\
\hline Non-student & 105 & $65 \%$ \\
\hline Total delegates & 161 & \\
\hline
\end{tabular}

Delegate Nationalities (largest delegation first, all other nationalities $\leq 5 \%$ )

\begin{tabular}{|l|l|l|}
\hline United Kingdom & 31 & $19 \%$ \\
\hline Australia & 25 & $16 \%$ \\
\hline United States of America & 16 & $10 \%$ \\
\hline Sweden & 13 & $8 \%$ \\
\hline The Netherlands & 9 & $6 \%$ \\
\hline
\end{tabular}

The growth in conference size also opened up new knowledge exchange and skilldevelopment opportunities for the seagrass scientists in attendance. To accommodate the larger number of delegates, the number of workshops was increased from three at the previous ISBW to twelve at ISBW12. The workshops allowed opportunities to develop social media, science communication, and seagrass restoration skills, as well as to discuss fostering infrastructure for seagrass monitoring and conservation in Southeast Asia. They also provided increased space for the type of group interaction that is not possible during contributed talk and poster sessions; on this occasion on topics like seagrass flowering, ecosystem resilience, and stressors.

A full list of the talks, posters, and workshops that made up the conference is available in the ISBW12 programme, which is attached as a PDF supplement to this paper.

\section{Growth in profile of research}

Previous descriptions of seagrass science in peer-reviewed literature have noted it to be of low recognition in the research and conservation communities when compared to the attention given to coral and even mangrove science (Cullen-Unsworth and Unsworth, 2016; Duarte, 1999; Orth et al., 2006; Unsworth and Cullen, 2010). A brief overview of the content presented at ISBW12 is evidence that seagrass research may now be turning a corner in 
terms of how it is perceived, with signs of it entering the scientific mainstream. Firstly, in his conference-opening plenary presentation, 'Securing a Future for Seagrass Meadows', Professor Carlos Duarte highlighted that while seagrass science is still less prolific than coral and mangrove science in terms of the number of peer-reviewed publications, it is now close to equally cited (12:10, https://www.youtube.com/watch?v=k0wkMF2G-YY). It was no surprise then, that in anecdotal feedback to conference organisers, and in posts on social media, delegates regularly remarked on the high quality of the contributed talks and posters that were presented as ISBW12 unfolded. Secondly, firm evidence of the greater profile for seagrass research could be seen in the work presented by some of the other plenary presenters. Delivering his talk on 'Seagrass Carbon Storage', Dr. Peter Macreadie presented work (Macreadie et al., 2015) that featured as a cover story for the Proceedings of the Royal Society B. Likewise, Professor Jeanine Olsen's plenary, 'Leveraging "Omics" for Seagrass Biology', included research (Olsen et al., 2016) that had featured on the cover of Nature, another leading journal covering all scientific fields.

\section{Growth in media coverage}

One of the main themes of Professor Carlos Duarte's plenary presentation was the rising public profile for seagrass meadows. Just as seagrass has had a lower profile than coral reefs in the scientific community, so it has been the case in mainstream and popular media (Duarte et al., 2008). Duarte described this transition as being from an "ugly duckling" to "a beautiful swan", showing evidence that coverage of seagrass in news media has exponentially grown since 2013 (50:29, https://www.youtube.com/watch?v=k0wkMF2G-YY). Much of this coverage, he said, had been optimistic, on topics such as seagrass recovery and ecosystem services. ISBW12 was itself the subject of two such positive reports identifiable by the Google News search engine; the first ever mentions on that platform of the "International Seagrass Biology Workshop". The stories in a daily national newspaper, The Scotsman, and on the citizen journalism platform NoFibs, both talked about the role of seagrass as a carbon sink (Englart, 2016; Lilley, 2016).

In addition, a statement highlighting the precarious conservation status of seagrasses, written by the World Seagrass Association (WSA) and signed by many of the ISBW12 delegates (Supplement, pp. 5-7), was released to coincide with the beginning of the conference. This statement was covered by the BBC (Briggs, 2016) and other outlets (Davis, 2016; "Gwynedd summit calls for action over plight of sea grass meadows," 2016; Tennenhouse, 2016, Unsworth et al., 2016). The positives of ISBW12 and seagrass science in general were also reported by the Welsh local media ("Scientists descend on the Llyn to discuss seagrass meadows," 2016).

\section{Growth in conference reach}

ISBW12 was perhaps the first ISBW to have an immediate scientific and conservation impact beyond the walls of the conference centre. Figures $2 a$ and $2 b$ show that online interest in seagrass heightened in the weeks prior to and during the meeting, likely due to social media use by delegates and the seagrass enthusiasts interacting with them and the release of the World Seagrass Association consensus statement. Over 100 people used the \#ISBW12 tag on Twitter during the meeting and there were close to 1,000,000 impressions (the number of times ISBW12 content was displayed) across Twitter, Instagram, and 
Facebook for the conference's final day. The meeting will also continue to have reach through this proceedings, and through the archived plenary presentations on YouTube (www.youtube.com/channel/UCGSHPIN3rgaE04a0bgzCYjw) and (with delegate blog commentaries) on Speak Up for The Blue (Chiquillo, 2017; Lilley, 2017; Smulders, 2017; Trevathan-Tackett, 2017; Unsworth, 2017).

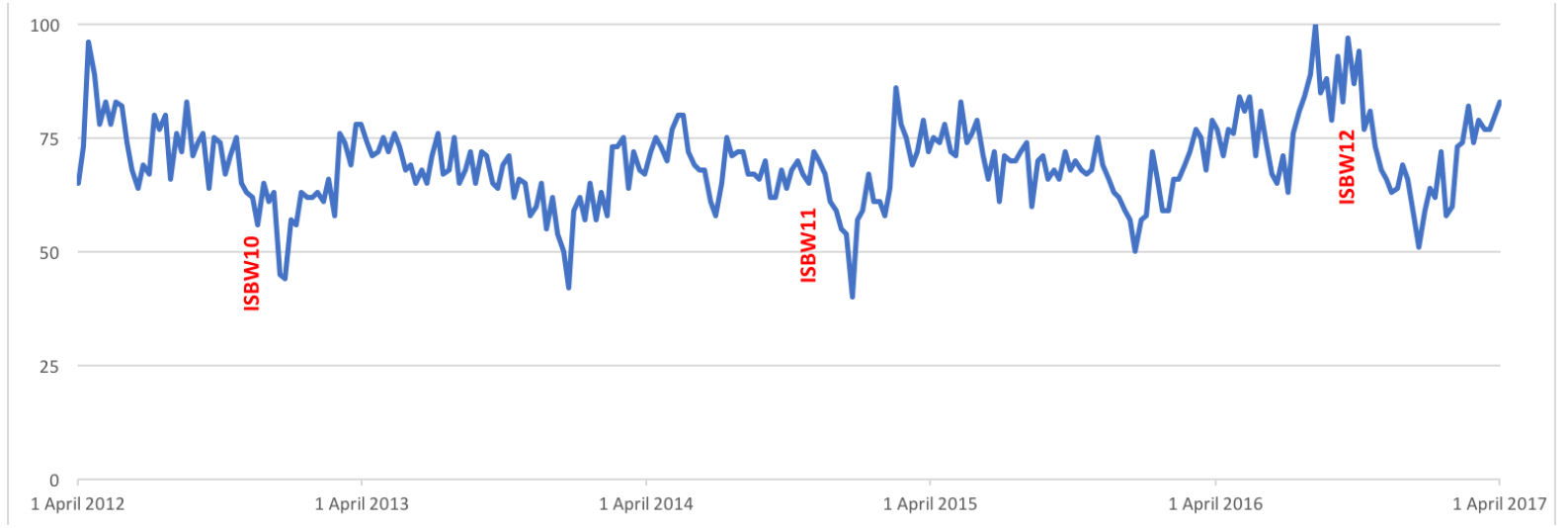

Figure 2a: Searches on the Google search engine for "seagrass" from $1^{\text {st }}$ April 2012 to $1^{\text {st }}$ April 2017, peaking during the ISBW12 dates. Data has been normalised (y-axis), where 100 $=$ the day with most searches for seagrass as a proportion of all Google searches, and $75=$ $75 \%$ the proportion of searches for seagrass as a proportion of all Google searches compared to the day with the most searches. Data source: Google Trends (www.google.com/trends).

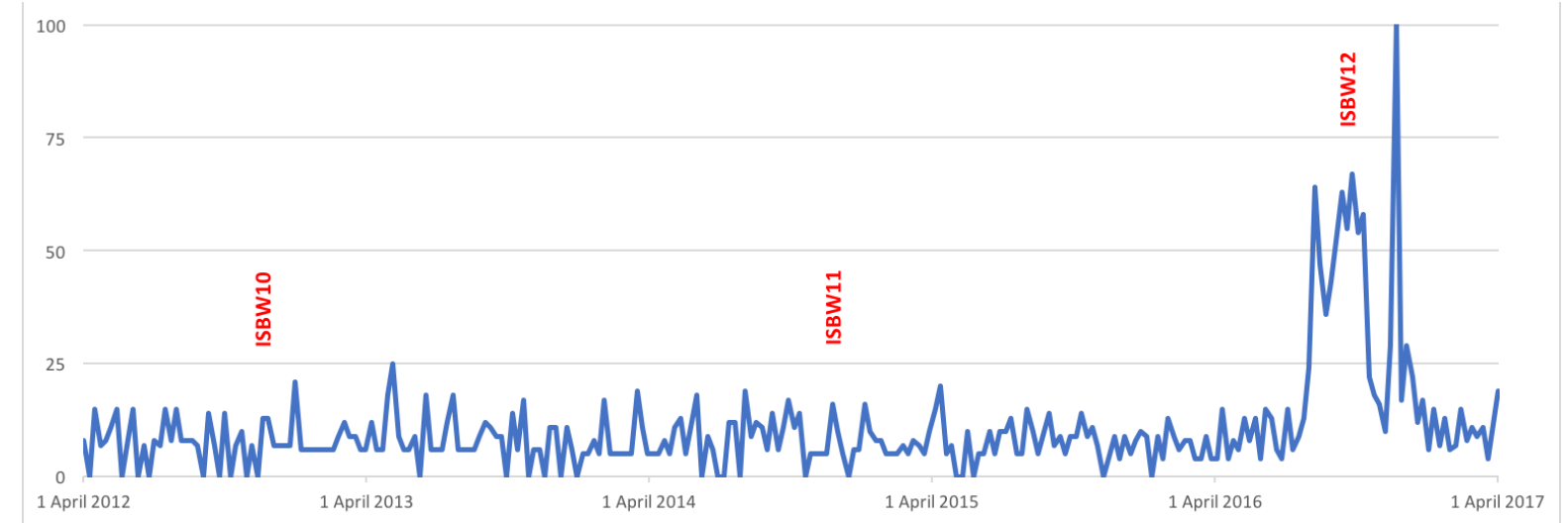

Figure 2b: Searches for "seagrass" on YouTube from $1^{\text {st }}$ April 2012 to $1^{\text {st }}$ April 2017, peaking during the ISBW12 dates. Data has been normalised (y-axis), where $100=$ the day with most searches for seagrass as a proportion of all YouTube searches, and $75=75 \%$ the proportion of searches for seagrass as a proportion of all YouTube searches compared to the day with the most searches. Data source: Google Trends (www.google.com/trends).

\section{Areas for continued and new seagrass science growth}

Some aspects of delegate diversity at ISBW12 were particularly encouraging. Table 1 illustrates that gender balance at the meeting was achieved. With initiatives like the adoption of a meeting Code of Conduct (ISBW12 was the first ISBW to have such a code), it is likely this will continue to be the case. The ISBW's reputation for being a safe space for all, no 
matter of their gender, gender identity, heritage, sexual orientation, or any other factor, should continue to grow as its scientific programme does.

Yet, despite an ISBW high of 28 nationalities being represented at ISBW12 (Coles at al., 2014), the data in Table 1 shows that the great majority of these came from nations where the financial barriers to conducting and participating in science are fewer. Several delegates had their visa applications for attending ISBW12 refused by UK Visas and Immigration who seemed to call their credibility as research professionals into question based on their nationality. Feedback to the conference organisers suggested that further potential delegates from so-called developing countries were unable to afford the financial costs of attendance. The ISBW does have progressive policies to encourage attendance from nations with less financial capacity to send delegates to ISBW, including alternating its location between so-called developed and developing nations (ISBWs have been held in the Philippines, Mexico, Tanzania, Thailand, China, and Brazil) (Coles et al., 2014). Further initiatives to support growth in the number of delegates from countries not well represented at ISBW12 and previous ISBWs should be encouraged for ISBW13 and beyond (e.g., support with visa applications, more travel scholarships).

The stronger focus given to conservation at this ISBW, as a result of the meeting theme, also opens up questions as to whether ISBW organisers and the WSA should do more to encourage social science programming going forward. There is no doubt that the specific focus on seagrass biology, as well as the relatively small meeting size, is a huge attraction of the ISBW series. This was the majority feedback to the authors of this paper in social sessions at the conference. Yet, seagrass meadows are intrinsically socio-ecological systems (Cullen-Unsworth et al., 2014) and social science is seen as a key ingredient in the conservation and continued existence of such threatened habitats (Bennett et al., 2017). Integrating social science into the ISBW series is a delicate issue, but surely one that can be overcome. The organisers of ISBW13 should consider its integration.

In making decisions on the future of the ISBW series, it also needs noting that the convenors of the series prefer an intimate meeting size (c. 100 delegates), as the meeting has become renowned for the high quality face-to-face discussions and knowledge sharing opportunities such a gathering allows (Coles et al., 2014). We suggest, however, that at 161 delegates, ISBW12 retained its intimate seagrass-focussed character. Some expansion in delegate numbers to accommodate the higher number of graduate students studying seagrass, as well as more developing world delegates, is both moral and important for the future development of seagrass science. Future annual general meetings of the WSA should review the preferred size for ISBWs so as to ensure that the workshops continue to be inclusive and comprehensive, while still being instantly recognisable as part of what has become a very successful series (Coles et al., 2014). The recurring People and the Sea conference, for instance, has remained intimate during growth to 250 delegates (Dr. Marloes Kraan, personal communication; https://www.youtube.com/watch?v=SQQyXnsqgKY). The ISBW would likely remain consistent in feel at 200-250 delegates.

\section{Conclusion: Plenty of reasons for \#OceanOptimism}

One of the workshops at ISBW12 was on the topic of ocean optimism (more commonly written as the social-media-friendly '\#oceanoptimism); the idea that positive examples of 
conservation needed to be sold to the public and policy-makers to foster further conservation. Certainly, the raised profile for seagrass as a result of the conference is a reason for optimism. The growth in seagrass science, evident in the ISBW growth, is now reminiscent of the growth in coral reef science, likewise evident in the growth of the International Coral Reef Symposium (ICRS) series, as the latter meeting transitioned from featuring basic research to being increasingly focused on management applications (Richmond and Wolanski, 2011). More people talking about the value of seagrass can only be a good thing for its survival prospects as a habitat. The conservation initiatives proposed in workshops, to mitigate anchor damage to seagrass in Wales and to take a more structured approach to management of Southeast Asian seagrasses, are further reasons for \#oceanoptimism. Other examples of \#oceanoptimism in the 121 delegate presentations are too great to list here.

The growth of ISBW thus far has been parallel to developments in the wider field of seagrass research (e.g. the setting up of the WSA, the inauguration of a 'Red List' of threatened seagrass species by the International Union for Conservation of Nature, see Coles et al., [2014] for further developments). The developments on show at ISBW12, of seagrass research on journal covers, as well as of higher media and social media profiles for seagrass, are of a similar magnitude. They should help fuel the growth of the ISBW series.

Seagrass science is in great health and has the potential to become even more impactful through the ISBW series. Until the eagerly awaited ISBW13, the new and vibrant online \#seagrass community will continue to meet via social media. ISBW12 was a successful, well-organised meeting, with the quality of delegate to which we can safely trust the future of seagrass research and conservation.

\section{Funding}

This research did not receive any specific grant from funding agencies in the public, commercial, or not-for-profit sectors.

\section{References}

Bennett, N.J., Roth, R., Klain, S.C., Chan, K.M.A., Clark, D.A., Cullman, G., Epstein, G., Nelson, M.P., Stedman, R., Teel, T.L., Thomas, R.E.W., Wyborn, C., Curran, D., Greenberg, A., Sandlos, J., Veríssimo, D., 2017. Mainstreaming the social sciences in conservation. Conserv. Biol. 31, 56-66.

Briggs, H., 2016. Call for action to protect "the lungs of the sea" [WWW Document]. BBC News. URL http://www.bbc.co.uk/news/science-environment-37606827 (accessed 4.12.17).

Chiquillo, K., 2017. "Leveraging omics for seagrass biology, management and restoration" By Prof. Jeanine Olsen 2016 [WWW Document]. Speak Up For Blue. URL http://www.speakupforblue.com/leveraging-omics-for-seagrass-biology-managementand-restoration-by-dr-jeanine-olsen-2016 (accessed 4.12.17).

Coles, R., Short, F., Fortes, M., Kuo, J., 2014. Twenty years of seagrass networking and advancing seagrass science: The International Seagrass Biology Workshop Series. Pac. Conserv. Biol. 20, 8-16.

Cullen-Unsworth, L.C., Nordlund, L.M., Paddock, J., Baker, S., McKenzie, L.J., Unsworth, R.K.F., 2014. Seagrass meadows globally as a coupled social-ecological system: Implications for human wellbeing. Mar. Pollut. Bull. 83, 387-397. 
Cullen-Unsworth, L.C., Unsworth, R.K.F., 2016. Strategies to enhance the resilience of the world's seagrass meadows. J. Appl. Ecol. 53, 967-972.

Davis, A., 2016. "Lungs Of The Sea" Must Be Protected, Loss Of Seagrass Is Bad News, Experts Warn [WWW Document]. Science World Report. URL http://www.scienceworldreport.com/articles/49448/20161012/lungs-sea-protected-lostseagrass-bad-news-experts-warned.htm (accessed 4.12.17).

Duarte, C.M., 1999. Seagrass ecology at the turn of the millennium: challenges for the new century. Aquat. Bot. 65, 7-20.

Duarte, C.M., Dennison, W.C., Orth, R.J.W., Carruthers, T.J.B., 2008. The Charisma of Coastal Ecosystems: Addressing the Imbalance. Estuaries and Coasts: J CERF 31, 233-238.

Englart, J., 2016. Coastal ecosystems could be major \#carbonsink says Australian researcher [WWW Document]. No Fibs. URL http://nofibs.com.au/coastal-ecosystemscould-be-major-carbonsink-says-australian-researcher-reports-takvera-bluecarbon/ (accessed 4.12.17).

Gwynedd summit calls for action over plight of sea grass meadows [WWW Document], 2016. . Cambrian News. URL http://www.cambriannews.co.uk/article.cfm?id=110060\&headline $=$ Gwynedd $\% 20$ summit $\% 20$ calls $\% 20$ for $\% 20$ action $\% 20$ over $\% 20$ plight $\% 20$ of $\% 20$ sea $\% 20$ grass $\% 20$ meadows\&sectionls=news \&searc hyear=2016 (accessed 4.12.17).

Lilley, R., 2017. Seagrass Resilience - Dr. Johan Eklof Resilience and Seagrass Ecosystem Feedback [WWW Document]. Speak Up For Blue. URL http://www.speakupforblue.com/seagrass-resilience-dr-johan-eklof-resilience-andseagrass-ecosystem-feedback (accessed 4.12.17).

Lilley, R., 2016. Loss of seagrass meadows is a carbon time bomb [WWW Document]. The Scotsman. URL http://www.scotsman.com/news/opinion/platform-loss-of-seagrassmeadows-is-a-carbon-time-bomb-1-4260640 (accessed 4.12.17).

Macreadie, P.I., Trevathan-Tackett, S.M., Skilbeck, C.G., Sanderman, J., Curlevski, N., Jacobsen, G., Seymour, J.R., 2015. Losses and recovery of organic carbon from a seagrass ecosystem following disturbance. Proc. Biol. Sci. 282, 20151537.

Olsen, J.L., Rouzé, P., Verhelst, B., Lin, Y.-C., Bayer, T., Collen, J., Dattolo, E., De Paoli, E., Dittami, S., Maumus, F., Michel, G., Kersting, A., Lauritano, C., Lohaus, R., Töpel, M., Tonon, T., Vanneste, K., Amirebrahimi, M., Brakel, J., Boström, C., Chovatia, M., Grimwood, J., Jenkins, J.W., Jueterbock, A., Mraz, A., Stam, W.T., Tice, H., BornbergBauer, E., Green, P.J., Pearson, G.A., Procaccini, G., Duarte, C.M., Schmutz, J., Reusch, T.B.H., Van de Peer, Y., 2016. The genome of the seagrass Zostera marina reveals angiosperm adaptation to the sea. Nature 530, 331-335.

Orth, R.J., Carruthers, T.J.B., Dennison, W.C., Duarte, C.M., Fourqurean, J.W., Heck, K.L., Hughes, A.R., Kendrick, G.A., Kenworthy, W.J., Olyarnik, S., Short, F.T., Waycott, M., Williams, S.L., 2006. A Global Crisis for Seagrass Ecosystems. Bioscience 56, 987.

Richmond, R.H., Wolanksi, E., 2011. Coral research: past efforts and future horizons. In Z. Dubinsky, N. Stambler, Coral reefs: an ecosystem in transition. Dordrect, the Netherlands: Springer, 3-10.

Scientists descend on the Llyn to discuss seagrass meadows [WWW Document], 2016. . Cambrian News. URL http://www.cambrian-

news.co.uk/article.cfm?id=109865\&headline=International\%20scientists $\% 20$ descend $\% 2$ 0on $\% 20$ the $\% 2$ Llyn $\% 20$ to $\% 20$ discuss $\% 20$ preservation $\% 20$ of $\% 20$ seagrass $\% 20$ meado ws\&sectionls=news\&searchyear=2016 (accessed 4.12.17).

Smulders, F., 2017. Seagrass-Herbivore Interactions: present, past and future [WWW Document]. Speak Up For Blue. URL http://www.speakupforblue.com/seagrassherbivore-interactions-present-past-and-future (accessed 4.12.17).

South China Sea Institute of Oceanology, 2014. The International Seagrass Biology Workshop was held in China for the first time [WWWW Document]. South China Sea Institute of technology. URL http://english.scsio.cas.cn/ns/es/201411/t20141130_132251.html (accessed 26.6.17). 
Stevens, R., Bressler, M., Silver, L., 2016. Challenges in Marketing Academic Conferences: A Pilot Study. Services Marketing Quarterly 37, 200-207.

Tennenhouse, E., 2016. Seagrasses, the "Lungs of the Sea," are in Peril [WWW Document]. The Science Explorer. URL http://thescienceexplorer.com/nature/seagrasses-lungs-seaare-peril (accessed 4.12.17).

Trevathan-Tackett, S., 2017. Securing a future for Seagrass Meadows [WWW Document]. Speak Up For Blue. URL http://www.speakupforblue.com/securing-a-future-forseagrass-meadows (accessed 4.12.17).

Unsworth, R., 2017. Ocean Optimism on the Future of Seagrass Meadows [WWW Document]. Speak Up For Blue. URL http://www.speakupforblue.com/ocean-optimismon-the-future-of-seagrass-meadows (accessed 4.12.17).

Unsworth, R.K.F., Cullen, L.C., 2010. Recognising the necessity for Indo-Pacific seagrass conservation. Conservation Letters 3, 63-73.

Unsworth, R.K., Jarvis, J., McKenzie, L., van Keulen, M., 2016. Seagrass is a marine powerhouse, so why isn't it on the world's conservation agenda? [WWW Document]. The Conversation. URL https://theconversation.com/seagrass-is-a-marine-powerhouseso-why-isnt-it-on-the-worlds-conservation-agenda-66503 (accessed 4.12.17).

York, P.H., Smith, T.M., Coles, R.G., McKenna, S.A., Connolly, R.M., Irving, A.D., Jackson, E.L., McMahon, K., Runcie, J.W., Sherman, C.D.H., Sullivan, B.K., Trevathan-Tackett, S.M., Brodersen, K.E., Carter, A.B., Ewers, C.J., Lavery, P.S., Roelfsema, C.M., Sinclair, E.A., Strydom, S., Tanner, J.E., van Dijk, K.-J., Warry, F.Y., Waycott, M., Whitehead, S., 2016. Identifying knowledge gaps in seagrass research and management: An Australian perspective. Mar. Environ. Res.

doi:10.1016/j.marenvres.2016.06.006 